\title{
Raz jeszcze o Paryżu Wokulskiego (u źródeł polskich rozpoznań własnej peryferyjności)
}

Michał Kuziak

TEKSTY DRUGIE 2020, NR 6, S. 368-386

DOI: 10.18318/td.2020.6.22 | ORCID: 0000-0002-7926-5268

I

W 1948 roku Jan Kott pisał o przebywającym w Paryżu bohaterze powieści Prusa jako o przybyszu z „kraju półkolonialnego"1. Wydaje się, że wiemy już wszystko o paryskim epizodzie Wokulskiego. Kwestii tej poświęcił książkę Krzysztof Rutkowski, dopatrując się sensów mistycznych owej historii². Pisano na ten temat w osobnych artykułach, a także w związku z innymi zagadnieniami interpretacyjnymi Lalki ${ }^{3}$. Można jednak raz

1 J. Kott O „Lalce"Bolesława Prusa, Książka, Warszawa 1948, s. 101. Cytat ten przywołuje T. Wójcik Paryska utopia Bolesława Prusa, "Przegląd Humanistyczny" 1990 z. 7, s. 129. O Wokulskim jako o bohaterze półperyferii (i związanym z tym szaleństwie) pisze F. Moretti The Bourgeois. Between History and Literature, Verso, London-New York 2013, s. 156 i nast.

2 Zob. K. Rutkowski Wokulski w Paryżu, słowo/obraz terytoria, Gdańsk 2010.

3 Poza cytowanymi dalej pracami warto wymienić: ). Kulczycka-Saloni Paris du XIXe siècle vu par un Polonais, w: Le livre et l'art. Études offertes en hommage à Pierre Lelièvre, ed. T. Kleindienst, Éditions Somogy,

Michał Kuziak - prof. dr hab., pracownik Zakładu Komparatystyki ILP UW. Autor książek poświęconych Mickiewiczowi (m.in. Inny Mickiewicz, 2013) i Słowackiemu (Fragmenty o Słowackim, 2001), retoryce (Jak mówić, rozmawiać, przemawiać?, kolejne wydania od 2005), a także artykułów dotyczących literatury romantycznej i współczesnej oraz teorii literatury i komparatystyki literackiej. Redaktor licznych książek zbiorowych, m.in. tomu Romantyzm środkowoeuropejskiw kontekście postkolonialnym (I-II). W kadencji 2020-2023 członek Komitetu Nauk o Literaturze PAN. 
jeszcze powrócić do podróży bohatera - podejmując wątek wskazany przez Kotta i odczytując ją jako zapis polskiego doświadczenia deficytu cywilizacyjnego i w efekcie tożsamościowego, kształtującego się w XIX wieku, po romantyzmie.

Deficyt ów, co nie bez znaczenia, ujawnia się wobec jednego z centrów nowoczesnej cywilizacji, jakim w XIX wieku była Francja. W Lalce opisane zostało niemal wszystko to, co wówczas wiązało się ze stosunkiem Polaków do niej. Utwór ten wypada potraktować zarazem jako świadectwo progu, który oddzielał dwie formuły tego zjawiska: romantyczną i poromantyczną. Z jednej strony Rzecki z politycznym marzeniem związanym z Napoleonidami kontynuuje tradycję romantyczną; ten wątek ciągnie się w literaturze polskiej od Mickiewicza przez Żeromskiego przynajmniej aż po Dygata (Jezioro Bodeńskie), nabierając w tym ostatnim przypadku wymiaru karykaturalnego. Z drugiej Wokulski napotyka nowoczesne miasto, Paryż, o którym przez wiele lat marzył - to zresztą także marzenie Izabeli i XIX-wiecznej polskiej artystokracji $^{4}$ - a teraz ma w nim robić interesy, poznać jego specyfikę. Przy czym, jak zauważa Józef Bachórz, w powieści nie pojawiają się romantyczne jeremiady antyurbanizacyjne ${ }^{5}$.

Znamienne, że przeżywanie Paryża ma w przypadku Wokulskiego charakter fantazmatyczny, dzięki czemu ujawniają się deficyty tożsamościowe i ekonomia pragnień bohatera ${ }^{6}$. Widać to $\mathrm{w}$ malignie towarzyszącej jego wędrówkom po mieście, w przemieszaniu jawy i snu. Trzeba jednak podkreślić, że nie mamy tu do czynienia z Benjaminowską fantasmagorią, oddającą - jak u Marksa - charakter kapitalizmu drugiej połowy XIX wieku. Wynikającą

Paris 2000; C. Zalewski Chaos i struktura. Paryż w "Lalce" Prusa, w: Obrazy stolic europejskich w piśmiennictwie polskim, red. A. Tyszka, Wydawnictwo AHE, Łódź 2010.

4 E. Paczoska przywołuje powieść A. Mańkowskiego Hrabia August, której bohaterowie nadają warszawskim ulicom francuskie nazwy, wytwarzając w ten sposób iluzję paryskości („Lalka”, czyli rozpad świata, Wydawnictwa Akademickie i Profesjonalne, Warszawa 2008, s. 30).

5 Zob. J. Bachórz Oswajanie miasta, „Przegląd Humanistyczny” 1992 nr 6, 75. Więcej na ten temat w literaturze polskiej: E. Rybicka Modernizowanie miasta. Zarys problematyki urbanistycznej wnowoczesnej literaturze polskiej, Universitas, Kraków 2003, s. 33 i nast.

6 Wypada przy tym pamiętać, że zdaniem R. Caillois (Paryż, mit współczesny, w: Odpowiedzialność i styl. Eseje, wybór M. Żurowski, przeł. K. Dolatowska, PIW, Warszawa 1967, s. 103 i nast.) miasto we współczesnej kulturze ogólnie nabiera mitycznego charakteru, w jego ujęciu wyobraźnia dominuje nad realnością.

7 O języku - retoryce miejskiej wędrówki - pisze M. de Certeau Wynaleźć codzienność. Sztuki działania, przeł. K. Thiel-Jańczuk, WUJ, Kraków 2008, s. 101 i nast. 
z tryumfu fetyszyzmu towarowego oraz procesów reifikacji. Skrywająca destrukcyjną naturę coraz bardziej płynnej nowoczesności ${ }^{8}$. W przypadku bohatera Lalki źródłem maligny jest historia miłosna, pamięć o Izabeli ścigającym go widmie. Wokulski mówi o chorobie duszy. Według profesora Geista myśli o samobójstwie. Pielęgnuje przy tym swój stan, m.in. za pomocą alkoholu, ale też usiłuje zrozumieć los i wyzbyć się iluzji. Pragnie zapomnieć o fatalnym uczuciu, zgubić się w tłumie, „odurzyć” pośród różnorodnych bodźców zmysłowych. Niezwykłość doświadczenia bohatera Prus akcentuje, wskazując na jego niejednoznaczny status ontyczny, na pojawienie się sobowtóra: „Było to jedno z najsilniejszych wstrząśnień, jakich doznał w życiu, sprawdziwszy własnymi oczyma, że tu, gdzie uważał się za zupełnie samotnego, towarzyszy mu niedostępny świadek... on sam!..." (s. 43)

Wyprzedzając dalsze rozważania, wypada zauważyć, że problem poznawczy, i w związku z tym tożsamościowy, bohatera wiąże się także z jego zdolnością do widzenia tego, czego żadną miarą nie mógł zobaczyć w Paryżu, oraz ignorowania tego, co zobaczyć mógłº .

II

Zapowiedzią pobytu Wokulskiego w Paryżu jest podróż: zmiana krajobrazu pokazuje, że zmierza on ku cywilizacji, na Zachód, w stronę centrum ówczesnego świata (nie przypadkiem zresztą w Paryżu bohater z peryferii lgnie do natury przytłoczony miejską architekturą); pojawiają się pasażerowie mówiący innymi językami, a także zachowujący się w odmienny od znanego podróżnikowi sposób. Pierwszym jego przewodnikiem po Paryżu - podkreślę: w czasie wystawy światowej (1878), a to, jak powiada Eric Hobsbawm, ważny aspekt wynajdywania tradycji dla nowoczesnego społeczeństwa w XIX wieku, element religii kapitalizmu ${ }^{11}$ - staje się Suzin. Również zachwycony

8 Zob. W. Benjamin Pasaże, red. R. Tiedemann, przeł. I. Kania, Wydawnictwo Literackie, Kraków 2003.

9 Wszystkie cytaty z Lalki za: B. Prus Lalka, t. 2, PIW, Warszawa 1987, lokalizacja podana w nawiasach po cytacie.

10 Jak zauważa S. Eile (Dialektyka "Lalki" Bolesława Prusa, "Pamiętnik Literacki” 1973 z. 1, s. 21), Paryż zostaje ukazany w powieści w subiektywnej perspektywie bohatera. Z kolei O. Tokarczuk przekonuje, że Lalka to powieść o iluzjach utrudniających dotarcie do prawdy (Lalka i perła, Wydawnictwo Literackie, Kraków 2001, s. 73).

11 Zob. E. Hobsbawm Masowa produkcja tradycji: Europa, lata 1870-1914, w: Tradycja wynaleziona, red. E. Hobsbawm, T. Ranger, przeł. M. Godyń i F. Godyń, Wydawnictwo UJ, Kraków 2008, s. 283. 
tym miastem przybysz z peryferii, choć to oczywiście peryferie o innym statusie niż nieistniejąca Polska, rosnące w siłę Imperium Rosyjskie. Podwojone spojrzenie przyjezdnych wzmacnia zachwyt stolicą Francji. Rosjanin okazuje się przepustką Wokulskiego do wielkiego świata, profesor Geist zwraca się zresztą do bohatera per „pan Siuzę"12. To jednak Polak staje się pośrednikiem, tłumaczem Suzina na Zachodzie. Prus zdaje się w ten sposób rozpoznawać i kreować skomplikowane wewnątrzsłowiańskie relacje kolonialne (być może ukazane w powieści polskie pragnienie Francji i Paryża ma intencjonalnie rys okcydentalistyczny i antyrosyjski).

Przypomina się tu autor Rodzinnej Europy piszący o swoim paryskim doświadczeniu, potrafiący zresztą spojrzeć krytycznie na stolicę imperium, które zawdzięcza swą siłę m.in. koloniom. Myślę zwłaszcza o epizodzie powojennym, z sowieckim dyplomatą upojonym tryumfem nad Niemcami, gardzącym Francją i szukającym zrozumienia dla tej postawy w bratnim Słowianinie. Poeta, patrząc z niesmakiem na francuskich intelektualistów ulegających urokowi rosyjskiej siły, zarazem dystansuje się od Rosjanina i jego wyższościowej postawy - stwierdza, że nie jest mu dostępna „Francja dyskretna i ukryta"13 , którą Miłosz mógł poznać dzięki O.W.M.

Słowiańscy parweniusze z Lalki mogą mieć w Paryżu wysoki status społeczny, bo pozwalają im na to pieniądze. Liczy się manifestowana wystawność. Wokulski jest w stolicy Francji panem, płaci, a nawet rozrzuca luidory (wspomnę, że lekcję takiego zachowania otrzymał wcześniej Kordian Słowackiego w Londynie). Je drogo, pije, gra w karty, oddaje się rozpuście ${ }^{14}$. Miasto chce mu się sprzedać - wzrok bohatera rozpoznaje/ustanawia je jako raj konsumpcji zaspokajający potrzeby ciała i skrywający logikę kapitalistycznej produkcji15 - a usłużny Jumart podpowiada podział ludzi w zależności od sposobów, w jakie pozyskują i wydają pieniądze. Mamy tu do czynienia z pozytywistycznym poglądem na rolę ekonomii kształtującej siłę państwa i jego

12 Zob. E. Paczoska „Lalka”, czyli rozpad świata, s. 142 i nast.

13 Cz. Miłosz Rodzinna Europa, Czytelnik, Warszawa 1990, s. 177. W przywołanej książce, a także w wierszu Rue Descartes, Miłosz pisze o swoim paryskim doświadczeniu barbarzyńcy przybywającego do "stolicy świata".

14 Zob. W. Forajter Rozpustny Wokulski: o aluzjach erotycznych w "Lalce” Bolesława Prusa, w: tegoż Pragnąć. Szkice o literaturze nowoczesnej, Wydawnictwo UŚ, Katowice 2017.

15 Zob. na ten temat). Baudrillard Społeczeństwo konsumpcyjne. Jego mity istruktury, przeł. S. Królak, Sic!, Warszawa 2006; H. Salmi Europa XIXwieku. Historia kulturowa, przeł. A. Szurek, Wydawnictwo UJ, Kraków 2010, s. 87 i nast. 
obywateli, choć sama, niejako kompensacyjna rozrzutność bohatera nie jest już pozytywistyczna, zdaje się ujawniać niechęć do akumulacji pieniądza ${ }^{16}$. Wypada jednak zauważyć w tym przypadku także pragnienie wytworzenia prestiżu".

Spostrzeżenie Ewy Paczoskiej - odnoszące się do kreacji przestrzeni Warszawy w Lalce - że pisarza interesowała struktura przeżywania miasta, zachowuje ważność także w odniesieniu do przedstawienia Paryża, traktowanego, powiada badaczka, jako „ogród kultury"18. Wokulski od samego początku pobytu w stolicy Francji przeżywa nowoczesność metropolii, zjawiska dotychczas mu nieznanego. Towarzyszy temu poczucie intensywności życia: "Oto miasto - myślał - w którym więcej przeżyłem w ciągu jednej godziny aniżeli w Warszawie przez całe życie...” (s. 95) ${ }^{19}$. Pierwsze wrażenie to „hałas, krzyk, bieganina”, natręctwo ludzi oferujących swoje usługi: „Ruch jest tak wielki, jak gdyby co najmniej połowa Warszawy biegła na zobaczenie jakiegoś wypadku" (s. 40 ${ }^{20}$. Bohater zwraca uwagę na rozbudowaną i zróżnicowaną komunikację, szerokie i równe ulice, olbrzymie place, bogactwo zabudowy mieszkalnej, użytkowej, ozdobnej. Obserwuje handlarzy, modnie ubranych ludzi, kawiarnie. Początkowo nie może nadążyć za tempem metropolii: „Idzie szybko, lecz pomimo to widzi, że wszystko go wyprzedza: powozy i piesi. Oczywiście, jest to jakiś olbrzymi wyścig" (s. 45). Zachwyca się przepychem hotelu (mieszka w Grand Hôtel - jednym z największych, najnowocześniejszych i najsłynniejszych w stolicy Francji), wystaw sklepowych, latającym balonem. Jest zdumiony: „czuł, że w tym miejscu może mu zabraknąć przymiotników i stopni najwyższych" (s. 6o). Konstruowany przez Prusa obraz Paryża epatuje spektaklem pełni - ogromem miasta oraz tempem życia i bogactwa

16 W ujęciu tym można znaleźć echo pozytywistycznego poglądu, zgodnie z którym to ekonomia kształtuje siłę narodu. Zob. B. Skarga Narodziny pozytywizmu polskiego 1831-1864, PWN, Warszawa 1964, s. 204.

Zob. T. Veblen Teoria klasy próżniaczej, przeł. J. i K. Zagórscy, wstęp J. Górski, PWN, Warszawa 1971 , s. 93 i nast.

Zob. E. Paczoska „Lalka”, czyli rozpad świata, s. 7.

19 Zob. K. Kościewicz Doświadczenie nowoczesności w "Lalce" $i$ „Emancypantkach" Bolesława Prusa, w: Bolesław Prus. Pisarz. Publicysta. Myśliciel, red. M. Woźniakiewicz-Dziadosz, S. Fita, Wyd. UMCS, Lublin 2003. mat, w związku z innymi tekstami literackimi, w swojej znakomitej książce K. Szalewska Urbanalia - miasto i jego teksty, słowo/obraz terytoria, Gdańsk 2017, s. 104 i nast.; warto tu wspomnieć także o rozważaniach autorki na temat spektakularności życia miejskiego, s. 83 i nast. 
przytłaczających coraz bardziej oszołomionego przybysza. To miasto po przebudowie przeprowadzonej według planów Georges'a Haussmanna. Opisał je wspomniany już Benjamin w Pasażach. Stolica Francji chciała być stolicą na miarę XIX wieku, stając się swego rodzaju mikrokosmosem ówczesnego świata, wraz z typowymi dla niego procesami kształtowania się nowoczesnej cywilizacji i kapitalizmu (poprawa kondycji zdrowotnej mieszkańców, ruch podporządkowany komunikacji kolejowej, łączącej centra przemysłu, handlu i rozrywki), znamiennymi dla niego fetyszami postępu, rynku, towaru²1.

\section{III}

Bohater porównuje paryską metropolię z Warszawą. To gest parweniusza, który w ten sposób kwestionuje wartość kraju swojego pochodzenia - co znamienne, wartość pojmowaną w kategoriach ekonomicznych ${ }^{22}$. Widok domniemanej opery wywołuje w Wokulskim rumieniec wstydu na myśl o własnym sklepie, który przecież jest ozdobą miasta, i prowadzi do konstatacji: „Ależ tu jest więcej marmurów i brązów aniżeli w całej Warszawie" (s. 45). W polu widzenia bohatera pojawiają się też paryskie sklepy: „Najlichszy z nich lepiej wygląda aniżeli jego, który jest najpiękniejszym w Warszawie" (s. 47). Nie chcąc mnożyć podobnych cytatów, przywołam jedynie coś w rodzaju pointy podsumowującej porównawczą refleksję Wokulskiego na temat obu miast: „Wkoło obszedł gmach myśląc o Warszawie. Z jakim trudem dźwigają się tamtejsze budowle, nieduże, nietrwałe i płaskie, gdy tu siła ludzka, jakby dla rozrywki, wznosi olbrzymy i tak dalece jest niewyczerpana pracą, że jeszcze zalewa je ozdobami" (s. 59). Ojczyzna tradycyjnie wymaga szczególnego trudu. Nie tylko, jak się okazuje, walki, ale i budowy. Rezultaty okazują się jednak problematyczne. Powstaje forma, która odznacza się słabością. We Francji, stwierdza dalej bohater, praca przynosi efekty. To zapewne doświadczenie realne, ale i wyraźna stygmatyzacja siebie jako Polaka. Wprawdzie tym, co łączy oba miasta (Paryż i Warszawę), jak czytamy,

21 Zob. D. Harvey Paris, Capital of Modernity, Routledge, New York-London 2003.

22 Zob. O. Tokarczuk Lalka i perła, s. 29 i nast. O Warszawie w Lalce zob. np. E. Paczoska „Lalka”, czyli rozpad świata, s. 17 i nast. (tu też rozważania o odmienności przedstawienia Paryża i Warszawy w powieści). W związku z poruszaną tu problematyką zob. także J. Sowa Fantomowe ciało króla. Peryferyjne zmagania z nowoczesną formą, Universitas, Kraków 2011. Wypada zauważyć, że komparatystyka Wokulskiego mieści się w zaproponowanym przez T. Zaryckiego modelu relacji centrów i peryferii; zob. tegoż Peryferie. Nowe ujęcie zależności centro-peryferyjnych, Scholar, Warszawa 2009, zwłaszcza rozdz. 6: Wzajemna percepcja centrów i peryferii. 
są złodzieje, ale w Warszawie mieszka wielu ludzi, „którzy nie wiadomo skąd czerpią dochody”. W związku z tym Wokulski stwierdza: „Może dlatego nie ma tam gmachów i łuków triumfalnych..." (s. 61). Polska okazuje się krajem niejasnych relacji ekonomicznych, co zapewne jest rezultatem sytuacji kolonialnego podporządkowania i przekłada się na ubóstwo kraju²3. Paryż to miasto akumulacji wszelkiego rodzaju kapitału, choć przecież - wypada zgłosić zastrzeżenie wobec świadomości bohatera - jak wiemy z kart powieści, również tam przeprowadza się podejrzane transakcje, handluje bronią. Życie we Francji okazuje się różnorodne i normalne, ludzie lubią i chcą się komunikować, kształtując w ten sposób kapitał społeczny, wytwarzając nowoczesną sferę publiczną; wypada dodać, że w kawiarniach toczy się życie nie tylko towarzyskie, ale i polityczne oraz kulturalne. Widok mniej okazałych budynków przynosi Wokulskiemu radość („napełnia go jakaś rzewność. Dom trzypiętrowy między pięciopiętrowymi!...cóż za miła niespodzianka”, s.46). Ratunek przed poczuciem podrzędności bohater znajduje w krytycyzmie, ma wrażenie, że już gdzieś widział te wszystkie wspaniałości, że w sumie to nic szczególnego, „mówi sobie, że - jakkolwiek w Paryżu częściej można słyszeć język francuski aniżeli w Warszawie, to jednak akcent tutejszy jest gorszy i wymowa mniej wyraźna" (s. 217). Wkrótce paryski nadmiar zaczyna nudzić bohatera. Przeżywa także przykre wydarzenia, ale wie, że nie zapomni tego, czego doświadczył. W znamienny sposób, znów sam siebie stygmatyzując, mówi: „Jestem dziki człowiek [...], więc wpadłem w obłęd, ale wydobędzie mnie z niego cywilizacja" (s. 72).

Podobne praktyki porównawcze widoczne są w kronikach Prusa. W tekście z 29 VI 1884 roku pisarz zajmuje się kwestią oszczędności, przywołując przykład Francji i Anglii, gdzie istnieje zwyczaj oszczędzania („Anglicy, naród praktyczny i zacięty...”). Kontrastuje z nim polską rozrzutność, ukazaną na przykładzie niedawno uwłaszczonych chłopów, którzy usiłują konkurować wystawnością życia ze szlachtą ${ }^{24}$. Sprawa nie jest jednak tak prosta. W kronikach możemy bowiem znaleźć także ironiczne przedstawienie dam z warszawskiego towarzystwa, nudzących się i marzących o innych krajach, zwłaszcza o Francji i Paryżu, gdzie przecież tyle się dzieje. W artykule z 5 VI 1887 roku krytyka dotyczy z jednej strony braku zainteresowania u kosmopolitycznego

23 Zob. Ł. Milenkowicz Literacka koegzystencja asynchronizmów. Wokół „Lalki"Bolesława Prusa, w: Ekonomie w literaturze i kulturze, red. B. Cymborowski i P. Tomczok, Wydawnictwo UŚ, Katowice 2017 , s. 17 i nast.

24 Zob. B. Prus Kroniki tygodniowe, oprac. Z. Szweykowski, t. 7, PIW, Warszawa 1958, s. 177. 
towarzystwa tym, co się dzieje w kraju (wystawy higieniczne, rozbójnicze napady w Lubelskiem, tragicznie kończące się swary rodzinne), z drugiej zaś zainteresowania tym, co modne i spektakularne, przy jednoczesnym ignorowaniu dorobku cywilizacyjnego (przykładem - myśl Newtona, odkryte przez niego prawo grawitacji): „Są damy i panowie, które i którzy poza obrębem salonu, toalety i kasy ogniotrwałej nie widzą nic więcej"25. Wypada tu dodać, że w Lalce arystokratyczne pragnienie Paryża jako miasta modnego przemienia się w doświadczeniu Wokulskiego w pragnienie utopii cywilizacyjnej.

Wątek porównywania powraca także w artykule z 20 VI 1897 roku. Prus utyskuje na brak oświaty wśród polskiego ludu, zwracając uwagę na jego niekonkurencyjność w stosunku do Niemców. Porównanie z Francją odnosi się do zaludnienia (gęstsze w Polsce), klimatu i bogactw naturalnych, umiejętności czytania (znów na korzyść Francji). Autor powiada: „Francja ma naturę bogatą, mnóstwo nagromadzonych skarbów materialnych i duchowych, wyborne drogi komunikacyjne. My zaś, przy ubogiej naturze, posiadamy bardzo mało zaoszczędzonych wytworów pracy i bardzo złe drogi"26. Sytuacja ta, przy braku oświaty, prowadzi do biedy wśród polskiej ludności, zaniedbywanej przez klasę wykształconą (która powinna nie tylko odpowiednio oświecać, ale i wychowywać), i klęski w wyścigu cywilizacyjnym.

Jak zauważa Bartłomiej Szleszyński, Paryż Wokulskiego nie jest Paryżem Prusa, który myślał o Francji w sposób bardziej skomplikowany i krytyczny niż jego bohater. Widział bowiem w tym mieście, inaczej niż Wokulski, zaprzeczenie nowoczesnej utopii ${ }^{27}$. W przywołanym artykule z 1887 roku pisarz zwraca uwagę na coś jeszcze, co nakazuje zweryfikować obraz Paryża zaproponowany przez niego w Lalce. Otóż polskie kulturalne towarzystwo nie tylko pomija dorobek nowoczesnej nauki, ale i nie zauważa protestów robotniczych w Belgii. Autor pozornie przyjmuje punkt widzenia osób, które nie rozumieją tych zajść (odmowy pracy, niszczenia fabryk), by ujawnić swoje stanowisko w następującej wypowiedzi: „Czyny zwierzęcej dzikości niezrozumiałe są dla ludzi ucywilizowanych, którzy jednak zapomnieli, że

25 B. Prus Kroniki tygodniowe, oprac. Z. Szweykowski, t. 10, PIW, Warszawa 1960, s. 138.

B. Prus Kronikitygodniowe, oprac. Z. Szweykowski, t. 15, PIW, Warszawa 1965, S. 149.

Zob. B. Szleszyński Dlaczego Wokulski nie pojechał do Londynu?, w: Podróż i literatura, red. E. Ihnatowicz, E. Paczoska, Wydawnictwo Wydziału Polonistyki UW 2008. Podobnie odmienność myślenia Prusa i Wokulskiego akcentuje W. Forajter Paryż Maxime'a Du Campa w oczach Stanisława Wokulskiego (rekonesans), w: tegoż Pragnąć, s. 85 i nast. Prus zobaczył Paryż dopiero po napisaniu Lalki. 
na dnie każdego społeczeństwa pracują i borykają się z nędzą istoty wcale nieucywilizowane"28. Prus dostrzega wyzysk, nierówności społeczne igroźbę śmierci głodowej zaglądającą w oczy robotnikom. Rozumie ich determinację wiodącą do niszczenia świata, który ich krzywdzi. Sytuacja ta, jak zauważa, grozi upadkiem cywilizacji. Niebezpieczeństwo takie pisarz widzi również w Polsce, postuluje więc konieczność pomocy klasie pracującej, uruchomienia szkół zawodowych - tego zadania powinni się podjąć ludzie z towarzystwa, trwoniący czas i pieniądze na wyścigach.

Ambiwalentne ujęcie Francji pojawia się w artykule z 12 XII 1889 roku. Prus zastanawia się, czy wystawa paryska dowodzi żywotności narodu francuskiego. Na arenie politycznej trudno powiedzieć, inaczej natomiast wygląda sprawa nauki, w której zdaniem autora Francja przoduje w Europie - choć nie posiada wielkich mędrców jak Anglia (Spencer) czy wielkich pisarzy jak Rosja (Tołstoj, Dostojewski, Szczedryn, Turgieniew), to jednak wyznacza kierunki rozwoju cywilizacji i literatury. Wywód znów jest ironiczny. Pisarz tropi ślady upadku kultury francuskiej (obraz Francji przypomina paryskich gości Wokulskiego), jej nihilistyczne oblicze, mające swoje źródło, jak się zdaje, w romantyzmie. Dostrzega jednakże zapowiedzi jej odrodzenia (m.in. w pisarstwie Bourgeta) ${ }^{29}$.

B. Prus, Kronikitygodniowe, t. 10, s. 139.

29

Zob. B. Prus Kroniki tygodniowe, oprac. Z. Szweykowski, t. 12, PIW, Warszawa 1962, s. 97 i nast. Jak pisze Antonina Kłoskowska, w latach 50. i 60. XIX wieku - zresztą nie bez kontrowersji związanych z krytyką mody na obce kultury - na łamach „Biblioteki Warszawskiej” (a także, dodaje badaczka, w większości ówczesnych czasopism) funkcjonuje stała rubryka publikująca korespondencję z Paryża. Jej autorka, Zofia Węgierska, prezentuje przedmiot doniesień jako kwintesencję i źródło cywilizacji mieszczańskiej, postępu, porewolucyjnej zmiany (dopiero w miarę upływu czasu niuansuje swoje ujęcie, dostrzegając darwinizm kapitalizmu i sprawę robotniczą, wciąż jednak myśli o społeczeństwie w optymistycznych kategoriach solidaryzmu), a także życia towarzyskiego, zapewne wytwarzając w ten sposób paryskie pragnienie. Badaczka zauważa wszakże, iż takim sytuującym się po stronie nowoczesności ujęciom Paryża towarzyszą w piśmie apologie sarmatyzmu; por. Francja i Paryż drugiego cesarstwa na łamach „Biblioteki Warszawskiej”. "Kronika Paryska"Zofii Węgierskiej (1853-1869), w: tejże Z historii i socjologii kultury, PWN, Warszawa 1969. Moda na Francję i Paryż jest zresztą widoczna w Warszawie o wiele wcześniej, można o niej mówić na przykładzie lat 20. XIX wieku, a początki tego zjawiska wiążą się ze schyłkiem I RP. W powieści Prusa pojawiają się też wzmianki na temat polsko-francuskiego projektu budowy bulwarów nadwiślańskich w Warszawie. Paryż jako miasto rozwiniętej cywilizacji, nastawionej na bogacenie się, naukę, postęp, a także rozrywkę, przedstawia w swoich pamiętnikach i dzienniku z lat 30. Julian Ursyn Niemcewicz - kontekstem tych obserwacji, co znaczące, często jest dramat Polski po powstaniu. 
Do galerii postaci zafascynowanych stolicą Francji można dodać np. bohatera Ludzi bezdomnych Żeromskiego, wiele lat później również Tadeusz Boy-Żeleński pisał o oszołomieniu pierwszym pobytem w Paryżu, podobnym do tego ukazanego przez Prusa, i o przemianie, której tam uleg ${ }^{30}$. Dopiero Gombrowicz stara się nie zachwycać Paryżem i zrezygnować z porównywania się z Zachodem. Przyjmując, że forma polska ma słaby charakter i odznacza się niedojrzałością, Gombrowicz zakłada, iż fakt ten może stanowić punkt wyjścia do rewizji formy europejskiej, odsłonięcia ogólnie słabego i niedojrzałego charakteru kultury ${ }^{31}$. Oczywiście po Gombrowiczu zachwyt Francją nie znika z kart polskiej literatury.

Powróćmy do Wokulskiego. Paryż ukazuje mu się jako ogrom nie do ogarnięcia. Systematycznie odrzucając bedeker - a więc stawiając na własne doświadczenie - bohater zajmuje specyficznie panoptyczną pozycję i wybiera miejsca do zwiedzenia. Poznaje również prawdziwe życie w różnych zakamarkach miasta, miejsca, „o których nie wspominają przewodniki: [wchodzi] do składów kupieckich, do warsztatów fabrycznych, do mieszkań rękodzielników, do kwater studenckich, do kawiarni i restauracyj na ulicach czwartego rzędu" (s. 63-64). Robi notatki. W chaosie miasta - odpowiadającym chaosowi jego wnętrza - rozpoznaje zasadę porządkującą w organiczny sposób rzeczywistość Paryża, eliminuje przypadkowośśc ${ }^{32}$. Odkrywa pracę historii odpowiedzialną za współczesny kształt. Rozważania te ujawniają scjentystyczną naturę bohatera, pragnienie uporządkowania doświadczenia zarówno przestrzennego, jak i społecznego: „Powoli jednakże, ku największemu zdziwieniu, spostrzegł, że ów Paryż, budowany przez kilkanaście wieków przez miliony ludzi, nie wiedzących o sobie i nie myślących o żadnym planie, ma jednakże plan, tworzy całość, nawet bardzo logiczną" (s. 67). Bez wątpienia bohater Lalki sytuuje się po stronie nowoczesności, która jeszcze pragnie ładu i jest przekonana, że może go ustanawiać, m.in. uobecniając przeszłość jako funkcję linearnego postępu.

Wokulski dostrzega w Paryżu postęp - fetysz nowoczesności - kumulatywny przyrost wartości, które świadczą o normalności życia, o tym, że nic się

30 Zob. T. Boy-Żeleński W Sorbonie igdzie indziej, w: WSorbonie i gdzie indziej, Nakładem Księgarni F. Hoesicka, Warszawa 1927.

31 Szerzej piszę na ten temat w artykule Prowincja - centrum. Strategie mocy i słabości literatury peryferyjnej (Mickiewicz - Gombrowicz - Stasiuk) , "Rocznik Komparatystyczny” 2015 nr 6.

32 Takie ujęcie czytelnik mógł znaleźć także w wydanym w 1889 roku w Warszawie Ilustrowanym przewodniku po Paryżu, podpisanym inicjałami H.N. 
nie marnuje (domyślnie - jak w Polsce): „Paryż jest arką, w której mieszczą się zdobycze kilkunastu, jeśli nie kilkudziesięciu wieków cywilizacji...” (s. 75). Bachórz zauważa, że ujęcie Prusa, kładące nacisk na zasób społeczny, na który składają się wartości materialne oraz duchowe, organicznie i harmonijnie tworzone przez kolejne pokolenia, bliskie jest myśli ekonomicznej Józefa Supińskiego i ogólnie ekonomii liberalnej33. Paczoska z kolei zwraca uwagę na kontekst dyskusji w „Wędrowcu” i myśl o polskiej kulturze oraz cywilizacji jako pozbawionych możliwości organicznego rozwoju - z powodu niewoli, zacierania śladów czasu przeszłego, związków z nim, zrywania ciągłości procesu rozwojowego ${ }^{34}$.

Wypada jednak dodać, że w przypadku Wokulskiego patrzącego na $\mathrm{Pa}-$ ryż mamy do czynienia ze swego rodzaju nadmiarem spojrzenia - bohater Prusa widzi to, czego nie widzą inni, bo też nie mogą, a przynajmniej nie powinni widzieć35. Tak jakby usilnie starał się uniknąć krytyki nowoczesnej świadomości kulturalnej, która pragnie wyzwolić od historii - krytyki sformułowanej w wiele lat po jego francuskim epizodzie przez Stanisława Brzozowskiego - bądź chciał uniknąć podejrzenia, że jest romantycznym kwiatem buntującym się przeciw swoim korzeniom. Paryż po przebudowie przeprowadzonej przez Haussmanna - na polecenie i w zgodzie z projektem Napoleona III - stał się przecież miastem, które zostało pozbawione swojej historii; dostrzeżona przez bohatera organiczność to efekt centralizacji wprowadzonej w trakcie przebudowy ${ }^{36}$. Projekt nowoczesności okazał się

33 Zob. J. Bachórz Wstęp, do: B. Prus Lalka, oprac. J. Bachórz, t. 1, Ossolineum, Wrocław 1991, s. XCV i nast.

Zob. E. Paczoska "Lalka", czyli rozpad świata, s. 33.

Wypada też za Arnoldem Hauserem stwierdzić, że Wokulski nie dostrzega blichtru Paryża. Badacz pisze: „Paryż [w czasach II Cesarstwa - M.K.] zyskuje nową okazałość, nowy wygląd wielkomiejski. Jego wielkość jest jednak często tylko pozorna, pretensjonalny materiał w rzeczywistości tylko surogatem, marmur tylko stiukiem, a kamień tylko zaprawą murarską. Wspaniałe fasady wyglądają jak przylepione, a bogate dekoracje są nieorganiczne i atektoniczne. Do architektury przenika rys niesolidności odpowiadający parweniuszostwu posiadającego władzę społeczeństwa. Paryż staje się powtórnie stolicą Europy, ale nie, jak dawniej, ośrodkiem sztuki i kultury, lecz metropolią rozrywek, miastem opery, operetki, balów, bulwarów, restauracji, domów towarowych, wystaw światowych, gotowych i tanich rozkoszy", A. Hauser Społeczna historia sztuki i literatury, przeł. J. Ruszczycówna, posłowie J. Starzyński, PIW, Warszawa 1974, s. 231; czytamy też u Hausera o eklektyzmie i braku jednorodnego stylu przebudowy Haussmanna.

36 Zob. R. Sennett Ciało i kamień. Człowiek i miasto w cywilizacji Zachodu, przeł. M. Konikowska, Aletheia, Warszawa 2015, s. 395 i nast. 
umocowany m.in. w zerwaniu z przeszłością. Bohater Prusa pragnie jednak uczynić z Paryża przestrzeń wszelkiej (nie)dostępnej rozkoszy.

\section{IV.}

Wokulski czuje się w Paryżu jak parweniusz. Flâneur z prowincji, obserwator gubiący się w tłumie, zewnętrzny wobec niego - choć inaczej niż bohater Baudelaire'a - wyobcowany przez peryferyjne pochodzenie, wierzący w utopię społeczną, poszukujący sensu. Przeżywa dziwność otaczającej go rzeczywistości, ,przyśpiesza kroku, a choć jeszcze nikogo nie wyścigną, już zwraca na siebie powszechną uwagę. Jego przede wszystkim atakują roznosiciele gazet i książek, na niego patrzą kobiety, z niego w drwiący sposób uśmiechają się mężczyźni" (s. 45-46) ${ }^{37}$. Fragment ten, toutes proportions gardées, przypomina doświadczenie Frantza Fanona zapisane w Czarnej skórze, biatych twarzach („A potem było nam dane stawić czoła białemu spojrzeniu”38). Wokulski zwraca uwagę autochtonów. Czuje na sobie ich wzrok, drwinę, jest onieśmielony, przeżywa wstyd. Chce spoliczkować kogoś, kto mu się przypatruje impertynencko, ostatecznie odpowiada spojrzeniem pełnym agresji: „jeden z nich impertynencko przypatruje mu się przez monokl. Gdybym tego franta uderzył w twarz? - myśli Wokulski. - Jutro pojedynek i może zabiłby mnie... Ale gdyby ja jego zabił?... Przeszedł około franta i spojrzał mu w oczy. Elegantowi monokl spadł na kamizelkę i opuściła go ochota do półuśmieszków" (s. 46-47). Dopiero po pewnym czasie bohater przestaje ustępować drogi miejscowym i wtapia się w tłum (co znamienne, w Paryżu tłumu nie tworzy biedota).

Doświadczenia paryskie stają się źródłem nie tylko poczucia zagubienia, ale i przyjemności, przynoszą Wokulskiemu naznaczone śladem masochizmu zadowolenie. To stwierdzenie powraca wiele razy: „Wędrówka na oślep w niezmiernym mieście była jedyną rzeczą mającą dla niego jakiś gorzki powab” (s. 228). Czytamy też: „tutaj jest onieśmielony jak dziecko i... dobrze mu z tym... Ach, jakże pragnąłby znowu zostać dzieckiem z owej epoki, kiedy to jego ojciec naradzał się z przyjaciółmi: czy go oddać do kupca, czy do szkół" (s. 46). Wokulskiemu wszystko imponuje, zachowuje się w związku z tym infantylnie, choć w Warszawie miał się za dorosłego. Przypomina

37 W związku z tą kwestią zob. W. Forajter Rozpustny Wokulski, s. 31 i nast.

38 F. Fanon Czarna skóra, białe maski, przeł. L. Magnone, w: Studia postkolonialne nad kulturą i cywilizacją polskq, red. K. Stępnik, D. Trześniowski, Wydawnictwo UMCS, Lublin 2010, s. 360. 
barbarzyńcę, ale już innego niż ten, o którym mówił Mickiewicz w Collège de France, mając na myśli Słowianina przynoszącego odrodzenie dekadenckiej Europie, wszczynającego wielką rewoltę, która odmieni oblicze świata - mającego stanowić wzór dla Europejczyka i Francuza ${ }^{39}$. Bohater Prusa przeżywa regres, który odsłoni swój sens związany z projektem nowego innego życia, odczuwa witalistyczny pęd i zarazem rodzaj przygniecenia: „Wokulskiemu zdaje się, że wydobyty z martwej wody wpadł nagle w ukrop, który «burzy się i szumi, i pryska...»” (s. 47); ale jest też „zdeptanym robakiem, który wlecze za sobą wnętrzności" (s. 61).

Snując rozważania na temat swojego życia, pogoni za różnymi marami (perpetuum mobile i loty balonem, stanowisko, kobieta), Wokulski „wyobrażał sobie, jak by to było, gdyby zamiast w Warszawie przyszedł na świat w $\mathrm{Pa}$ ryżu" (s. 244). Dochodzi do wniosku, że Francuzi to ludzie interesu, praktyczni, rozsądni, nawet miłość traktują w sposób trzeźwy - choć przecież trudno nie zauważyć, że do bohatera lgną też oszuści, a los ubogiego geniusza, profesora Geista, oraz jego uwagi pod adresem współczesnego społeczeństwa, żyjącego dogmatami i wykorzystującego wynalazki w złym celu, zdają się przynajmniej ograniczać wizję francuskiej racjonalności ${ }^{40}$. Bohater ma wizję normalnego - wygodnego - życia w Paryżu: państwowych instytucji edukacyjnych, otwartych dróg rozwoju i kariery, tradycji nauki i techniki, wspólnot, które się nimi zajmują, braku barier w relacjach społecznych: „W żadnym zaś wypadku nie traktowano by go jak Murzyna w Ameryce” (s. 73). „Ja-inny” z Paryża ma w wyobraźni bohatera bez wątpienia łatwiejsze i bardziej twórcze życie. Ma także świadomość, że w Polsce był wykorzystywany przez tych, którzy chcieli uczynić z niego swojego sługę i wpoili mu imperatyw walki o ich idee. Myśląc w ten sposób, Wokulski kwestionuje uniwersalną wartość polskiego kapitału moralnego, przeciwstawianego od czasów romantyzmu europejskiemu kapitałowi materialnemu.

Celem Francuza - stwierdza bohater - jest życie szczęśliwe, dlatego zapobiega on zmęczeniu (powozy), walczy z nudą (teatry, widowiska) i ciemnotą (muzea, biblioteki, odczyty), dba o higienę (kanalizacja, szerokie ulice pozwalające na cyrkulację powietrza), zaspokaja potrzeby konsumpcyjne (fabryki), żyje blisko natury (wyjazdy za miasto bądź do „lasku”) i kultury (Luwr, muzea, gabinety).W centrum paryskiego świata znajduje się człowiek i jego potrzeby, 
związana z nim troska (ale też troska o zwierzęta i drzewa!), harmonia, brak konfliktów. Wokulskiemu wszystko wydaje się piękne i użyteczne, a także dostępne, trwałe i czyste, eksponujące utopię zakorzenienia: „Dzięki troskliwości o wszystko przedmioty znajdujące się w Paryżu przynoszą wielorakie korzyści. [...]. Francuz, gdy coś wytwarza, dba naprzód o to, ażeby dzieło jego odpowiadało swemu celowi, a potem, ażeby było piękne" (s. 75) ${ }^{41}$. Miasto przebudowane przez Hausmanna wytworzyło nowy styl życia i nową figurę kapitalizmu - konsumenta.

Paryż w Lalce to utopia bez wątpienia tyleż realistyczna (Bachórz), co fantazmatyczna ${ }^{42}$. Wskazuje jednak na potęgę cywilizacji odpowiedniej do aspiracji Wokulskiego - bohatera kapitalistycznej, jeszcze pełnej optymizmu nowoczesności: „A cóż oni robią?... Przede wszystkim nadzwyczajnie pracują" (s. 74). Praca trwa bez względu na wszystko. Odznacza się specjalizacją. Słabi giną, silni zaspokajają swoje pragnienia, panuje darwinizm ekonomiczny i społeczny, który bohater uznaje wszakże za coś pozytywnego; rozwój polega na bogaceniu się rodów, akumulacji bogactwa. Tomasz Wójcik akcentuje w związku z tym rolę ewolucjonizmu społecznego, patrzenia w powieści na proces historyczny jak na przyrodniczy, podporządkowany optymistycznie pojętej logice rozwoju ${ }^{43}$. Wokulski jest zafascynowany energią kapitalizmu, nowoczesnego człowieka, tym, co współczesny filozof Peter Sloterdijk nazywa „odhamowaniem" i co stopniowo będzie ujawniać swoje negatywne cechy ${ }^{44}$.

Wokulski nie zna diagnoz alienacji Karola Marksa (utopia cywilizacyjna to zdaniem bohatera poręczne narzędzie człowieka) czy wspomnianych rozważań Benjamina o fantasmagorii paryskiej, nie dostrzega w nowoczesnej zasadzie rozwoju groźby upłynnienia świata i podmiotu. Nie wie, że z centrum przebudowywanego Paryża wywłaszczono biedotę, a szerokie ulice

41 Zob. w związku z tym H. Hazel Hahn Scenes of Parisian Modernity. Culture and Consumption in the Nineteenth Century, Palgrave Macmillan, New York 2009.

42 J. Bachórz pisał, że to utopia realistyczna, widział jednak jej pęknięcia (Oswajanie miasta, s. 74). Pomija je w swojej interpretacji Wójcik (Paryska utopia Bolesława Prusa), z którym polemizuje w związku z tą kwestią Paczoska („Lalka”, czyli rozpad świata, s. 144 i nast.). Na temat utopii naukowej w powieści zob. A. Smuszkiewicz Fantastycznonaukowy fragment "Lalki" Bolesława Prusa, w: Na pozytywistycznej niwie, red. T. Lewandowski, T. Sobieraj, Wydawnictwo PTPN, Poznań 2002.

Zob. T. Wójcik Paryska utopia Bolesława Prusa, s. 126 i nast.

44 Zob. P. Sloterdijk Kryształowy pałac. O filozoficznq teorię globalizacji, przeł. B. Cymbrowski, Wydawnictwo Krytyki Politycznej, Warszawa 2011, s. 85. Ponadto: E. Hobsbawm The Age of Capital 1848-1875, Vintage, London 1996. 
miały służyć między innymi łatwiejszemu przemarszowi wojska używanego do tłumienia wybuchających buntów (nowoczesność funduje się również na przemocy); jak wspomniałem, nie jest świadom tego, że kilka lat wcześniej przez miasto przetoczyła się kolejna rewolta ${ }^{45}$. Haussmannowska przebudowa stolicy była odpowiedzią na kryzys 1848 roku. Miała realizować zasadę akumulacji przez urbanizację, rozwiązując problemy z nadpodażą kapitału i bezrobociem. Efektem okazał się jednak kryzys 1868 roku, związany z przerostem i spekulacyjnym charakterem uruchomionego systemu kredytowego, i przegrana wojna z Niemcami, która miała stanowić wyjście z trudnej sytuacji ekonomicznej. Wypadki Komuny Paryskiej, jak pisze David Harvey, wynikały m.in. z nostalgii za światem zniszczonym przez Haussmanna (korzystającego z nowoczesnych rozwiązań urbanistycznych, używających żelaza i szkła), a także z chęci odzyskania przejętego przez kapitał miasta ${ }^{46}$.

Jak kontrapunkt dla świadomości Wokulskiego brzmią słowa Fryderyka Engelsa na temat Londynu:

Gdy kto powałęsał się kilka dni po głównych ulicach [...], dopiero wtedy spostrzega, że ci londyńczycy musieli poświęcić najlepszą cząstkę swego człowieczeństwa, aby dokonać tych wszystkich cudów cywilizacyjnych, od których roi się ich miasto, że ogromne drzemiące w nich siły nie zostały uruchomione, lecz stłumione. ${ }^{47}$

Można tu też przypomnieć wizję Paryża, która pojawia się na gruncie francuskiej powieści od Stendhala przez Balzaka po Zolę, i ukazuje miasto jako przestrzeń wspomnianego już „odhamowania”, a także kształtujących się

45 Jak pisze E. Paczoska, Prus z zawartego w powieści obrazu Paryża usunął odniesienia do miasta z pierwszej połowy XIX wieku, żyjącego kolejnymi rewoltami oraz ideami wolnościowymi („,Lal$k a^{\prime \prime}$, czyli rozpad świata, s. 143).

Zob. D. Harvey Bunt miast. Prawo do miasta i miejska rewolucja, przeł. zespół, Bęc Zmiana, Warszawa 2012, s. 25 i nast. Jak zauważa autor, Haussmann, przebudowując Paryż, podjął projekt socjalistów utopijnych, który wszakże zrealizował z większym, niż zakładali, rozmachem.

47 F. Engels Położenie klasy robotniczej w Anglii, przeł. A. Długosz, w: K. Marks, F. Engels Dzieła, t. 2, Książka i Wiedza, Warszawa 1961, s. 299. O tym, że Prus widział mankamenty kapitalizmu w związku z polską rzeczywistością transformacyjną drugiej połowy XIX wieku przekonuje D. Gawin "Lalka" - powieść o transformacji, w: Polska, wieczny romans. O zwiqzzach literatury i polityki wXX wieku, Ośrodek Myśli Politycznej, Kraków 2005. Na temat Paryża w drugiej połowie XIX wieku zob. np. krytyczne ujęcie A. Kłoskowskiej Francja i Paryż drugiego cesarstwa na łamach „Biblioteki Warszawskiej”. "Kronika Paryska” Zofii Węgierskiej (1853-1869), zob. ponadto E. Kaczyńska Pejzaż miejski z zaściankiem w tle, Fundacja Res Publica, Warszawa 1999. 
konfliktów społecznych ${ }^{48}$. Prusowi, powtórzę, bliższa była właśnie taka, krytyczna wizja stolicy XIX wieku. Bohater powieści nie zna ponadto kolonialnego kontekstu bogactwa Francji.

Ukazane tu doświadczenia i przemyślenia sprawiają, że w Wokulskim krystalizuje się poczucie, że zmarnował życie, roztrwonił swoje zdolności i energię, nie uczynił nic dla rozwoju cywilizacji: „Jestem człowiek zmarnowany. Miałem ogromne zdolności i energię, lecz - nie zrobiłem nic dla cywilizacji. Ci znakomici ludzie, jakich tu spotykam, nie mają nawet połowy moich sił i mimo to zostawiają po sobie machiny, gmachy, utwory sztuki, nowe poglądy" (s. 76), Refleksja bohatera, jak zgodnie podkreślają badacze, wprowadza wątek krytyki polskiego społeczeństwa ${ }^{49}$. W Paryżu, jak się okazuje, ludzie o mniejszych zdolnościach robią większe rzeczy niż w Polsce. Przede wszystkim dlatego, że przyjmują życie, jakim jest, żyją szczęśliwi, są użyteczni, realizują swoje możliwości. Wokulski natomiast żył marami, musiał zmagać się z ciężkim losem i w ostatecznym rozrachunku wiele zawdzięczał przypadkowi. Jak mówi, nie mógł się uczyć, gdyż w jego kraju potrzebni byli sprzedawcy, a służba ojczyźnie wiązała się z walką pozbawioną programu - walką, o której ofiarach zapomniano. Brakowało pracy. Nie pozwolono bohaterowi założyć rodziny, jakiej pragnął. Żeby żyć pełnią szczęścia w Warszawie, trzeba było mieć pieniądze i towarzystwo do kart. Nie znajdowali tam miejsca ludzie, którzy oprócz żołądka mieli duszę łaknącą miłości i wiedzy:

Tu naczelnych miejsc nie obsiada pleśń podejrzanej starożytności, ale wysuwają się naprzód istotne siły: praca, rozum, wola, twórczość, wiedza, nawet piękność i zręczność, a nawet choćby szczere uczucie. Tam zaś praca staje pod pręgierzem, a triumfuje rozpusta! Ten, kto dorabia się majątku, nosi tytuł sknery, kutwy, dorobkiewicza; ten, kto go trwoni, nazywa się: hojnym, bezinteresownym, wspaniałomyślnym... Tam prostota jest dziwactwem, oszczędność wstydem, uczoność równo znaczy z obłędem, artyzm symbolizuje się dziurawymi łokciami. Tam, chcąc zdobyć miano człowieka, trzeba posiadać albo tytuł z pieniędzmi, albo talent wciskania się do przedpokojów (s. 110).

48 Zob. P. Parkhurst Ferguson Paris as Revolution. Writing the Nine-teenth Century City, University of California Press, Berkeley-Los Angeles-Cambridge 1997. 
Los Wokulskiego, jak przekonuje historia XIX wieku, okazuje się alegorią losu Polaków, którzy dopiero po spełnieniu patriotycznych obowiązków mogli angażować się w rozwój cywilizacyjny kraju (np. Ignacy Łukasiewicz) bądź mogli włączyć się w proces kształtowania nowoczesności jedynie na emigracji (np. Ignacy Domeyko) ${ }^{50}$.

Wyjaśnienie, jak się zdaje ironiczne, różnicy dzielącej Polskę i Francję znajduje Wokulski w odmienności klimatu. W Paryżu jest cieplej, ludzie mają więcej energii i twórczej siły, którą spożytkowują na pracę duchową. Człowiek Północy natomiast marnuje swój potencjał, borykając się z ograniczeniami natury. Bardziej wiarygodnie brzmi jednak wyjaśnienie społeczne: arystokracja kwestionuje kategorię zasługi, uniemożliwiając rozwój ambitnym i zdolnym parweniuszom: „Tak silnie wierzono w powagę rodu, że nawet synowie rzemieślników i handlarzy albo kupowali herby, albo podszywali się pod jakieś zubożałe rody szlachetne. Nikt nie miał odwagi nazwać się dzieckiem swoich zasług" (109-110). Świat polski jest anachroniczny - rozmija się z procesami nowoczesności, gardzi pracą i rozwojem, wyrzeka się merytokracji51.

Jeżeli, jak stwierdza Tadeusz Sławek: miasto jest ,s p o s o b e m is t n i e nia przestrzeni, który umożliwia artykułowanie naszych uczuć i doznań wobec przestrzeni"52, to w przypadku Paryża z powieści Prusa artykułowana jest problematyka tożsamościowa, i to nie tylko związana z miłosnym doświadczeniem bohatera ${ }^{53}$, ale i ta odnosząca

50 C. Michalski w poświęconym Lalce artykule akcentuje z kolei opisaną przez Prusa i trwającą do dzisiaj sytuację „zhierarchizowania” i „zablokowania” polskiego społeczeństwa przez zjawisko wykluczającego salonu, por. tegoż "Boję się twojej trzeźwości", "Tygodnik Powszechny” 2012 $\mathrm{nr} 40$.

51 Problematykę polskiej modernizacji w XIX wieku przedstawił w znakomitej książce J. Jedlicki Jakiej cywilizacji Polacy potrzebują: studia z dziejów idei i wyobraźni XIX wieku, PWN, Warszawa 1988.

T. SławekAkro/nekro/polis: wyobraźnia miejskiej przestrzeni, w: Pisanie miasta-czytanie miasta, red. A. Zeidler-Janiszewska, Wydawnictwo Fundacji Humaniora, Poznań 1997, s. 19.

53 Jak się zdaje, nie przypadkiem Lalka nie staje się osobnym przedmiotem w rozważaniach P. Tomczoka poświęconych "podmiotowi kapitalistycznego pragnienia w literaturze polskiej” (Podmiot kapitalistycznego pragnienia w literaturze polskiej, w: Literackie ekonomie, red. P. Wolskio, P. Tomczok, Wydawnictwo UŚ, Katowice 2017), pragnienie to jest bowiem w przypadku bohatera zarazem napędzane i kwestionowane przez konsekwencje wynikające z jego pragnienia erotycznego. Na tę kwestię zwraca uwagę F. Jameson w artykule A Businessman in Love, w: The Novel, ed. F. Moretti, vol. 2, Princeton University Press, Princeton and Oxford 2006, s. 436 i nast. Badacz pisze o Wokulskim jako o bohaterze nierozstrzygalności. Do problemu nieokreśloności pragnienia Wokulskiego Tomczok wraca w studium Ekonomie „Lalki" Bolesława Prusa, 
się do losu polskiego w świecie nowoczesnym. Wokulski to przybysz z „kraju półkolonialnego",jak pisał Kott. Rozpoznaje swoją podrzędność cywilizacyjną i usiłuje ją kompensować posiadanym majątkiem (ten ma jednak niejasne pochodzenie). Choć uzależniony od rosyjskiego przyjaciela, zarazem jest mu niezbędny jako tłumacz dysponujący większym kapitałem kulturowym. Prus zwraca ponadto uwagę na charakteryzujące Polskę zjawisko kolonizacji wewnętrznej - Wokulski to także parweniusz w swojej ojczyźnie, mającej charakter stanowy, wiążącej się z dominacją arystokracji.

\section{***}

Lalka, jej epizod paryski, przedstawia moment, w którym rodzi się i zostaje wypowiedziany polski wstyd związany z modernizacją, a także utrwala się jej imitacyjny model charakterystyczny dla (pół)peryferii54. Oczywiście nie chodzi tu o ścisłość dat, ale o zjawisko związane z drugą połową XIX wieku, będące pochodną kształtującej się ekspansywnie w Europie nowoczesności ${ }^{55}$. Jak wspomniałem, Wokulski to już inny barbarzyńca niż ten Mickiewiczowski, mający zawstydzić Europę w związku z jej odejściem od ideałów wiary i wolności ${ }^{56}$. To człowiek w nowoczesnym sensie ekonomiczny, traktujący

w: Literacki kapitalizm. Obrazy abstrakcji ekonomicznych w literaturze polskiej drugiej połowy XIX wieku, Wydawnictwo UŚ, Katowice 2018, s. 578 i nast.

54 Zob. w związku z tą kwestią rozważania Ł. Milenkowicza Literacka koegzystencja asynchronizmów.

55 Wypada przywołać tu przykład wcześniejszej podróży na Zachód, którą odbywa Słowacki W roku 1831 (jej świadectwo zostało zapisane w listach poety). W tym przypadku nie widać poczucia pochodzenia z peryferii i niższości cywilizacyjnej, podróżnik z ciekawością obserwuje nieznany sobie świat; wyraża pozytywne emocje - zwłaszcza wobec Londynu - okazuje się krytyczny wobec Paryża i Francuzów; Słowackiego zajmuje inność, koloryt lokalny porównywany z tym, co polskie. Zob. W. Weintraub Dwa Paryże, w: tegoż Od Reja do Boya, PIW, Warszawa 1977. Podobnie rzecz przedstawia się w Kartkach z podróży J.I. Kraszewskiego, który w 1871 roku ukazywał swój pobyt w Paryżu z końca lat 50. U pisarza pojawia się wyrazisty dyskurs krytyczny wobec kapitalizmu i burżuazji, spleciony z tradycyjną opozycją miasta i wsi, uruchamiającą krytykę nowoczesnej cywilizacji odpowiedzialnej za upadek moralności. Pisze na ten temat A. Czajkowska Józef Ignacy Kraszewski wobec postępu cywilizacyjnego w Europie. Na marginesie relacji z podróży, „Pamiętnik Literacki” 2015 z. 2. Można jednak zapytać, czy wspomniana krytyczność nie stanowi rewersu niewypowiedzianego jeszcze poczucia podrzędności. Podobnie antycywilizacyjne diatryby Mickiewicza z Ksiagg narodu i pielgrzymstwa polskiego wolno odczytywać jako resentymentalny rewers pragnienia.

56 Jedna z (nomen omen) reakcji na nowoczesność może w drugiej połowie XIX wieku mieć charakter romantyczny $\mathrm{i}$ wiązać się z krytycznym rozpoznaniem nowoczesności. W odniesieniu do 
świat jako przestrzeń inwestycji, zysków i strat, a przy tym rozpoznający swoją peryferyjność, uwikłanie w historię, trwałość fatalnych struktur społecznych i kulturowych, specyficznej ekonomii symbolicznej i społecznej polskości utrudniających wejście na drogę modernizacji. Powieść ukazuje również narodziny Wielkiego Innego Polaków - Europejczyka, Francuza (i w efekcie narodziny tożsamości, która jest umocowana w geście porównania i związanym z tym afekcie wstydu). Polskie doświadczanie nowoczesności w przypadku Wokulskiego okazuje się ponadto zapośredniczone i zdeformowane przez fantazmaty egzystencjalne, wiąże się z aspiracjami, niezrozumieniem zachodzących procesów i ich konsekwencji, bezkrytyczną afirmacją, która przecież wiedzie - musi wieść - do wielu rozczarowań.

\section{Abstract}

\section{Michał Kuziak}

UNIVERSITY OF WARSAW

Once More on Wokulski's Paris: At the Sources of Poland's Understanding of Its Own Marginality

Rereading Bolesław Prus's novel The Doll, Kuziak explores how the protagonist Wokulski experiences Paris. This perspective sheds light on the emergence of Poland's marginal position in the nineteenth-century world system, where Paris was a centre of civilisation. Prus's novel portrays the birth of the Poles' Great Other in the nineteenth century - the European, notably the French, and it provides an analysis of the reasons of Poland's marginality.

\section{Keywords}

Bolesław Prus, The Doll, Lalka, modernisation, postcolonial criticism, marginality, the city in literature

Sienkiewicza i jego doświadczenia paryskiego pisze na ten temat M. Gloger Sienkiewicz nowoczesny, Wydawnictwo UJK, Bydgoszcz 2010, s. 78 i nast. Inną romantyczną strategię przyjmuje w tym czasie Norwid, ignorując nowoczesne miasto - szerzej piszę na ten temat w artykule Norwid i pejzaż nowoczesności. Wokół Paryża poety, ,"Studia Norwidiana” $2014 \mathrm{nr} 32$. 